\title{
Paleonutrient Data Analysis of the Glacial Atlantic Using an Adjoint Ocean General Circulation Model
}

\author{
A. M. E. Winguth, D. Archer \\ Department of Geophysical Sciences, University of Chicago, Illinois \\ E. Maier-Reimer, and U. Mikolajewicz \\ Max-Planck-Institut für Meteorologie, Hamburg, Germany
}

\begin{abstract}
In this study we assimilate measurements of stable carbon isotope compositions $\delta^{13} \mathrm{C}$ and the ratio of cadmium to calcium ( $\mathrm{Cd} / \mathrm{Ca}$ ) concentrations from marine sediments into an ocean general circulation model to reconstruct the flow field of the deep-sea during the last glacial maximum (LGM) 21,000 years ago. The results of the assimilation confirm that the southward flow of North Atlantic Deep Water was shallower during the LGM and this was accompanied by a strong source of glacial North Atlantic Intermediate Water. The optimized glacial flow field in the Southern Ocean is consistent with the $\mathrm{Cd} / \mathrm{Ca}$ measurements but can not explain $\delta^{13} \mathrm{C}$ changes, suggesting a breakdown of the glacial phosphate- $\delta^{13} \mathrm{C}$ relationship.
\end{abstract}

\section{INTRODUCTION}

Reconstructions of the ocean circulation during the last glacial maximum (LGM) by ocean general circulation models (OGCMs) [Fichefet et al., 1994; Seidov and Haupt, 1997; Herterich et al., 1999; Winguth et al., 1999], coupled models with reduced complexity of the ocean-atmosphere system [Fieg, 1996; Ganopolski et al., 1998; Weaver et al., 1998], or fully coupled oceanatmosphere GCMs (integrated only over short periods of 15 years)[Bush and Philander, 1998] are generally based on paleoclimatic evidence. The paleo deep-sea circulation is commonly deduced from stable carbon isotope compositions $\left(\delta^{13} \mathrm{C}\right)$ and the ratio of cadmium

Inverse Methods in Global Biogeochemical Cycles Geophysical Monograph 114

Copyright 2000 by the American Geophysical Union to calcium $(\mathrm{Cd} / \mathrm{Ca})$ concentrations from foraminifera shells in marine sediments [Boyle, 1992; Sarnthein et al., 1994; Michel et al., 1995]. Although the models try to reproduce the main features of the glacial to interglacial changes, significant differences occur in some regions between the model studies and the observational data base which are caused by uncertainties in: 1 . formulation of the models, 2 . surface boundary conditions of heat, salinity, and wind, and 3. the data.

The model formulation of OGCMs is dependent on the temporal and spatial resolution and internal parameterization of physical and geochemical processes. For example, high resolution OGCMs allow to resolve eddies in the ocean and a detailed description of the geophysical dynamics [Semtner and Chervin, 1992]. One disadvantage of the use of these models are the high computational expenses of the forward and inverse algorithms [van Oldenborgh et al., 1997].

The second critical problem is the uncertain recon- 
struction of the forcing boundary conditions for past times. The ventilation of the deep-sea is sensitive to variations of the thermohaline conditions on the surface, especially to surface salinities in regions with suitable conditions for deep water formation (e.g. the Nordic Sea and the Weddell Sea). Uncertainties in reconstructed surface salinity data from the ratio of ${ }^{18} \mathrm{O}$ to ${ }^{16} \mathrm{O}$ isotopes $\left(\delta^{18} \mathrm{O}\right)$ in foraminifera shells [Duplessy et al., 1991] are dependent on several exchange processes of the ocean-atmosphere-cryosphere system: For example, 1 . about $2 / 3$ of the glacial-interglacial variations in the $\delta^{18} \mathrm{O}$ of the foraminifera shells are caused by imperfectly known changes in the continental ice volume. 2. The fractionation between the ${ }^{18} \mathrm{O} /{ }^{16} \mathrm{O}$ ratios in the shells and the ${ }^{18} \mathrm{O} /{ }^{16} \mathrm{O}$ ratio of the surrounding water $\left(\delta^{18} \mathrm{O}_{\mathrm{w}}\right)$ depends on the past temperature in seawater [Shackleton, 1974] which is only known to certain degree. 3. Deviations of up to 0.5 in salinity from the modern linear salinity- $\delta^{18} \mathrm{O}_{\mathrm{w}}$ relation [Labeyrie et al., 1992] are observed in the Southern Ocean because formation of sea ice influences salinity but has little impact on $\delta^{18} \mathrm{O}_{\mathrm{w}}$ [Zahn and Mix, 1991]. If the modern linear salinity- $\delta^{18} \mathrm{O}_{\mathrm{w}}$ relation is taken to reconstruct the glacial salinities, then large errors occur because of the imprecisely known extent of sea ice coverage and thickness.

Also, recent proxy data for sea surface temperature (SST) show discrepancies to the Climate: Long Range Investigation, Mapping, and Prediction (CLIMAP) Project Members [1981] reconstruction in polar regions [Weinelt et al., 1996; Rosell-Melé and Koc, 1997; A. de Vernal, personal communication, 1997]. Evidence from measurements of $\mathrm{Sr} / \mathrm{Ca}$ in corals from Barbados [Guilderson et al., 1994], noble gases in ground water from Brazil [Stute et al., 1995], alkenones [Sikes and Keigwin, 1994], and snow line depressions [Rind and Peteet, 1985] indicate also a LGM tropical SST [Farrera et al., 1999] $2^{\circ}-4^{\circ} \mathrm{C}$ colder than temperature reconstructions from the CLIMAP Project Members [1981].

Atmospheric modelling studies such as the Paleomodelling Intercomparison Project (PMIP) [Joussaume and Taylor, 1995] do significantly depend on the forcing surface temperature reconstructions. Thus, the reliability of the outcome of these studies, e.g. the wind fields which in turn are used to force the OGCMs, are strongly related to the quality and uncertainties of the surface temperature reconstructions. Winguth et al. [1999] studied the relation of glacial type surface buoyancy fluxes and wind fields and the deep-sea circulation. Their model results (using restoring boundary conditions) indicate a much weaker relation between wind stress in the Southern Ocean and the Atlantic deep-sea circulation than the previous study of Toggweiler and Samuels [1993]. Winguth et al. [1999] concluded that changes of the surface salinities is the most uncertain and effective boundary condition to control the ventilation of the deep-sea. However, their results strongly depend on the way the models are parametrized (e.g., internal friction, choice of numerical scheme, boundary conditions [Rahmstorf and England, 1997], or topography [McDermott, 1996]).

Besides uncertainties due to model formulation and surface boundary conditions, inconsistency in the reconstruction of the glacial nutrient distribution estimated from $\delta^{13} \mathrm{C}$ and the $\mathrm{Cd} / \mathrm{Ca}$ of calcareous foraminifera shells has obscured our view of the glacial ocean circulation [Boyle, 1992; Broecker, 1993; Yu et al., 1996]. Both paleonutrient proxies indicate a shallower and reduced North Component Water (NCW), but appear to be inconsistent in the Southern Ocean [Boyle, 1992; Sarnthein et al., 1994, Francois et al., 1997].

In this study we present a method by which an OGCM can be adjusted to fit the paleonutrient data as a means to reduce the uncertainty in the circulation patterns and surface boundary conditions for the last glacial period. Our study focuses on the reconstruction of the glacial Atlantic, where most of the data are available, and seeks to answer the following questions:

1. What does the reconstruction of the paleonutrient distribution from marine sediment cores tell us about the ocean circulation during the last glacial maximum?

2. How should surface salinity boundary conditions be modified to result in a circulation close to that predicted by the paleonutrient data?

3. How sensitive is an OGCM to changes in the salinity boundary conditions?

\section{MODEL}

A description of the current version of the Hamburg large scale geostrophic OGCM (LSG)[Maier-Reimer et al., 1993] is given by Winguth et al. [1999]. The Hamburg LSG uses a $72 \times 72 \mathrm{E}$ grid [Arakawa and Lamb, 1977] (approximately $3.5^{\circ} \times 3.5^{\circ}$ horizontal resolution), 11 vertical layers, and has a time step of one month. The temperature and salinity in the surface layer were computed by a Newtonian coupling to prescribed air temperatures and salinities. The sea ice model is a simple thermodynamic model including a wind dependent ice advection. Further details are found in Mikolajewicz [1996]. Coupling coefficients of $40 \mathrm{~W} \mathrm{~m}^{-2} \mathrm{~K}^{-1}$ for temperature and $1.5 \times 10^{-5} \mathrm{~m} \mathrm{~s}^{-1}$ for salinity yield (with a 
50-m thick top layer) time constants for both properties of approximately 60 and 40 days, respectively.

A biological model - the "soft tissue pump" of the HAMOCC3 [Maier-Reimer, 1993] - with phosphate, particulate organic matter, and oxygen as additional prognostic variables is coupled on-line to the OGCM for this study. The model assumes a constant Redfield stoichiometry for particulate organic mater [Takahashi et al., 1985]:

$$
P: N: C: \Delta O_{2}=1: 16: 127:-172
$$

where $\Delta \mathrm{O}_{2}$ denotes the amount of released oxygen during the biological production. Phosphate, the limiting nutrient, is consumed by primary prodiction in the surface and released in the deep-sea by remineralization. Here, we modeled these processes as in Winguth et al. [1999].

Were there no air-sea fractionation, then the distribution of $\delta^{13} \mathrm{C}$ values within the sea should be tightly correlated with phosphate. During photosynthesis ${ }^{12} \mathrm{C}$ is fixed with slight preference over ${ }^{13} \mathrm{C}$ yielding a fractionation for organic matter of $-20 \%$ for modern times and $-18 \%$ for the LGM [Rau et al., 1991]. Because plant material is formed only in the mixed layer and some of the material is oxidized only after falling to deeper layers of the sea, $\delta^{13} \mathrm{C}$ in the surface layer is higher than that in deep waters. To calculate $\delta^{13} \mathrm{C}$ diagnostically from phosphate we use a linear relationship after Broecker and Maier-Reimer [1992] (see formula (2) in Winguth et al. [1999]). The total $\delta^{13} \mathrm{C}$ distribution $\left(\delta^{13} \mathrm{C}_{\text {tot }}\right)$ in the deep-sea can be described by

$$
\delta^{13} \mathrm{C}_{\text {tot }}=\delta^{13} \mathrm{C}_{\text {bio }}+\delta^{13} \mathrm{C}_{\mathrm{as}} \approx \delta^{13} \mathrm{C}_{\text {bio }}+c
$$

where $\delta^{13} \mathrm{C}_{\text {bio }}$ describes the "soft tissue pump" and $\delta^{13} \mathrm{C}_{\text {as }}$ denotes the carbon isotope fraction by the airsea gas exchange on the surface. $\delta^{13} \mathrm{C}$ in the deep Atlantic can be approximated by the effect of the biological pump, where $\mathrm{c}$ is a constant chosen to be $-0.2 \%$ for modern times. Winguth et al. [1999] showed with a carbon cycle model coupled on-line to an OGCM that in first order the effect of the gas exchange $\delta^{13} \mathrm{C}_{\text {as }}$ in the deep-sea can vary for glacial and interglacial times in the same range as the observational error of the $\delta^{13} \mathrm{C}$ data.

\section{DATA}

$\delta^{13} \mathrm{C}$ data are taken from analysis of benthic foraminifera shells from the study of Sarnthein et al. [1994] and Michel et al. [1995]. The analytical reproducibility of $\delta^{13} \mathrm{C}$ is up to $\pm 0.04 \%$ for $\delta^{13} \mathrm{C}$ (Kiel laboratory) [Sarn- thein et al., 1994]. However, deviations between $\delta^{13} \mathrm{C}$ measurements of the foraminiferal shells and dissolved inorganic carbon (DIC) in deep water are much larger, in the order of $\pm 0.2 \%$ as shown in Figure 6 (b) in Sarnthein et al. [1994] or in McCorkle and Keigwin [1994]. Here, we assume the same observational error of $\pm 0.2 \%$ as in the study of LeGrand and Wunsch [1995]. It has been deduced that $\delta^{13} \mathrm{C}$ of pore water and $\delta^{13} \mathrm{C}$ gradients between the sediment surface and the surrounding water significantly influence the $\delta^{13} \mathrm{C}$ incorporated into the foraminiferal shells ("Mackensen effect") [Mackensen et al., 1993]. The authors showed that $\delta^{13} \mathrm{C}$ in $F$. Wuellerstorfi can differ locally up to $-0.5 \%$ from the ratio in the bottom water because of seasonal flux variations of organic carbon [Mackensen, 1997]. However, since these processes at the sedimentwater interface are not known in detail we do not consider the Mackensen effect in our model.

A glacial-interglacial change of $-0.4 \%$ derived from deep Pacific sediment cores is assumed in our study, which implies a $600 \mathrm{GtC}$ loss of carbon during glacial times from the land biosphere (see Crowley [1995] for a review). Glacial-interglacial changes in the land biosphere are recently estimated to be $850 \pm 300 \mathrm{GtC}$ (Table 2 in Crowley [1995]). Thus, carbon and $\delta^{13} \mathrm{C}$ differences between the estimates from the land biosphere and marine sediment cores are $250 \pm 300 \mathrm{GtC}$ and $0.2 \pm 0.2 \%$ respectively. Spero et al. [1997] showed a $\mathrm{pH}$ dependence on the ${ }^{13} \mathrm{C} /{ }^{12} \mathrm{C}$ and ${ }^{18} \mathrm{O} /{ }^{16} \mathrm{O}$ ratio of calcareous foraminiferal shells. The observed glacial-interglacial shift of $-0.4 \%$ thus can possibly be explained simply by a higher $\mathrm{pH}$ of seawater during glacial times [Sanyal et al., 1995].

$\mathrm{Cd} / \mathrm{Ca}$ in the water column follows in first order phosphorus $(\mathrm{P})$ in the ocean with the "global" Cd-P relationship $(\mathrm{Cd}=0.208 \mathrm{P}$ for $\mathrm{P}<1.34$ and $\mathrm{Cd}=0.279+$ 0.398(P-1.34) for $\mathrm{P}>1.34)$ [Boyle, 1988]. Here, we used the method of Boyle [1992] to transform the $\mathrm{Cd} / \mathrm{Ca}$ data from the foraminifera shells into phosphate concentrations of the water column which could then be directly compared with the simulated phosphate values of the water column. Cd distribution coefficients between $\mathrm{Cd}$ (foram) and Cd (water) are taken from a depth dependence relationship (1.3 for $\mathrm{z}<1150 \mathrm{~m}, 1.3+(\mathrm{z}-1150)(1.6$ /1850) for $1150 \mathrm{~m}<\mathrm{z}<3000 \mathrm{~m}$, and 2.9 for $\mathrm{z}>3000 \mathrm{~m}$ ) [Boyle, 1992]. The $\mathrm{Cd} / \mathrm{Ca}$ data applied in this study are taken from Boyle [1992]. Rosenthal et al. [1997] summarized several mechanisms which have been offered to explain the apparent paleoceanographic conundrum between $\mathrm{Cd} / \mathrm{Ca}$ and $\delta^{13} \mathrm{C}$ in the Southern Ocean. 1. The Mackensen effect for $\delta^{13} \mathrm{C}, 2$. the effect of $\delta^{13} \mathrm{C}$ gas exchange by deep open ocean convection (e.g. by 
Southern Ocean polynyas) [Mackensen et al., 1996], 3. postdepositional dissolution of $\mathrm{Cd} / \mathrm{Ca}$, and 4 . changes in Cd inventory. However, the latter two effects are assumed to be a second-order phenomenon (at least for the Holocene) [Rosenthal et al., 1997].

\section{INVERSE METHOD}

The inverse technique we used in our study is the adjoint method, which provides the best fit of a dynamical model to a given data set and has been discussed and applied in several studies (see Wunsch [1997], and Giering [1999] for a review). A schematic overview of the configuration of the inverse OGCM is displayed in Figure 1.

\subsection{Control Variables and Cost Function}

The variational problem is to find a solution of the model equations and control variables $\alpha$ which minimizes the total cost function $J_{\text {TOT }}$ over some temporal and spacial domain. $J_{\text {TOT }}$ is defined by a summation of the data cost function $J_{\mathrm{D}}$ and the penalty cost functions $J_{\mathrm{P}}$ and $J_{\mathrm{w}}$ at time $t$ and grid location $i j k$. The data cost function describes the distance between the paleonutrient data $\mathbf{y}^{\mathbf{0}}$ and the simulated model values $\mathbf{x}_{\mathrm{P}}$. Penalty terms $J_{\mathrm{P}}$ and $J_{\mathrm{w}}$ are introduced to penalize large differences between the a priori and a posteriori phosphate concentrations $\left(x_{P}\right)$ and vertical velocities $\left(\mathbf{x}_{\mathbf{w}}\right)$. If model equations are assumed to be perfect, then the trajectory simulated by the model depends only on the initial conditions at time $t=t_{0}$ and on the boundary conditions. $J_{\text {TOT }}$ can be written thus:

$$
\begin{aligned}
J_{\mathrm{TOT}} & =J_{\mathrm{D}}+J_{\mathrm{P}}+J_{\mathrm{w}} \quad \text { with } \\
J_{\mathrm{D}} & =\sum_{t} \sum_{n} \sum_{i j k} \mathrm{R}_{n, i j k}\left(\mathrm{x}_{\mathrm{P} t, i j k}-\mathrm{y}_{n}^{0}\right)^{2} \\
J_{\mathrm{P}} & =\sum_{t} \sum_{n} \sum_{i j k}\left(\mathrm{P}_{\mathrm{P}}\right)_{n, i j k}\left(\mathrm{x}_{\mathrm{P} t, i j k}-\mathrm{x}_{\mathrm{P}_{t_{0}, i j k}}\right)^{2} \\
J_{\mathrm{w}} & =\sum_{t} \sum_{i j k}\left(\mathrm{P}_{\mathrm{w}}\right)_{i j k}\left(\mathrm{x}_{\mathrm{w} t, i j k}-\mathrm{x}_{\mathrm{w} t_{0}, i j k}\right)^{2}
\end{aligned}
$$

with weights

$$
\begin{aligned}
\mathrm{R}_{n, i j k} & =\frac{W_{n}}{\sigma_{\mathrm{D}}^{2}} \frac{\mathrm{dv}_{i j k}}{\mathrm{~V}_{D}}, \\
\left(\mathrm{P}_{\mathrm{P}}\right)_{n, i j k} & =\frac{W_{n}}{\sigma_{\mathrm{P}}^{2}} \frac{\mathrm{dv}_{i j k}}{\mathrm{~V}_{D}}, \\
\left(\mathrm{P}_{\mathrm{w}}\right)_{i j k} & =\frac{W_{\mathrm{w}}}{\left(\sigma_{\mathrm{w}}^{2}\right)_{i j k}} \frac{\mathrm{dv}_{i j k}}{\mathrm{~V}_{t o t}} .
\end{aligned}
$$

We decided to modify the uncertain surface salinity re- constructions to optimize the glacial ocean circulation. This assumption is based on results from Winguth et al. [1999] (see also references therein) studying the sensitivity of paleonutrient tracer distributions and deep-sea circulation to glacial boundary conditions. One major difficulty of the work presented here is the sparsity of salinity data: only $\mathbf{3 3 0}$ observations are globally available, which is $\sim 10$ times lower than the amount of surface salinity boxes in the model. We solve this problem of underdetermination by condensing the amount of control variables into amplitudes $\alpha$ of a few orthogonal large-scale patterns. We chose the first 30 eigenfunctions of the Laplace operator on the model grid with vanishing gradients normal to the coast, which is appropriate for scalar quantities. The eigenfunctions were obtained by a repeated application of the Ritz procedure, which yields a series of eigenvalues in descending order.

The weighting matrix $\mathbf{R}$ denotes the observation error covariance matrix which we assume to be diagonal, i.e. that the data are independent and normally distributed. For the standard deviation of the data $\sigma_{\mathrm{D}}$ we used a value of $\pm 0.2 \mu \mathrm{mol} \mathrm{L}^{-1}$. This value is based on the assumed error of $\pm 0.2 \%$ for the $\delta^{13} \mathrm{C}$ data. The covariance matrix for $\mathbf{P}_{\mathrm{P}}$ is with $\sigma_{\mathrm{P}}=\sigma_{\mathrm{D}}$ chosen to be the same as the observation error covariance matrix. The matrix $\mathbf{P}_{\mathbf{w}}$ contains the standard deviation of the vertical velocities $\sigma_{\mathrm{w}}$ and is calculated from the seasonal variance for modern times. The parameter $W_{n}$ describes the distance to the data location and $W_{\mathrm{w}}$ the influence of a smooth vertical velocity field. The weight $W_{\mathrm{w}}$ is set to be $10^{-6}$ on the grounds that the choice led to stable results for interglacial and glacial simulation [see Winguth, 1997]. $\mathrm{V}_{\text {tot }}$ is the total ocean volume and $\mathrm{V}_{D}$ is the sum of all box volumina $\mathrm{dv}_{i j k}$ used for the assimilation.

\subsection{Adjoint Model}

We constructed the adjoint model by inversion of the computer code of the forward model, a common technique for GCMs demonstrated by Talagrand [1991]. With this method the statements of the forward model are transformed using the chain rule into a tangent linear statement (the linearized code) and inverted into an adjoint statement. The structure of this inversion is generally systematic and thus automatic procedures can be applied. The adjoint Hamburg LSG has partly been generated by the tangentlinear and adjoint model compiler (TAMC) [Giering and Kaminsky, 1996]. The direct inversion of the model code presented here has some major differences to an earlier version of the adjoint 


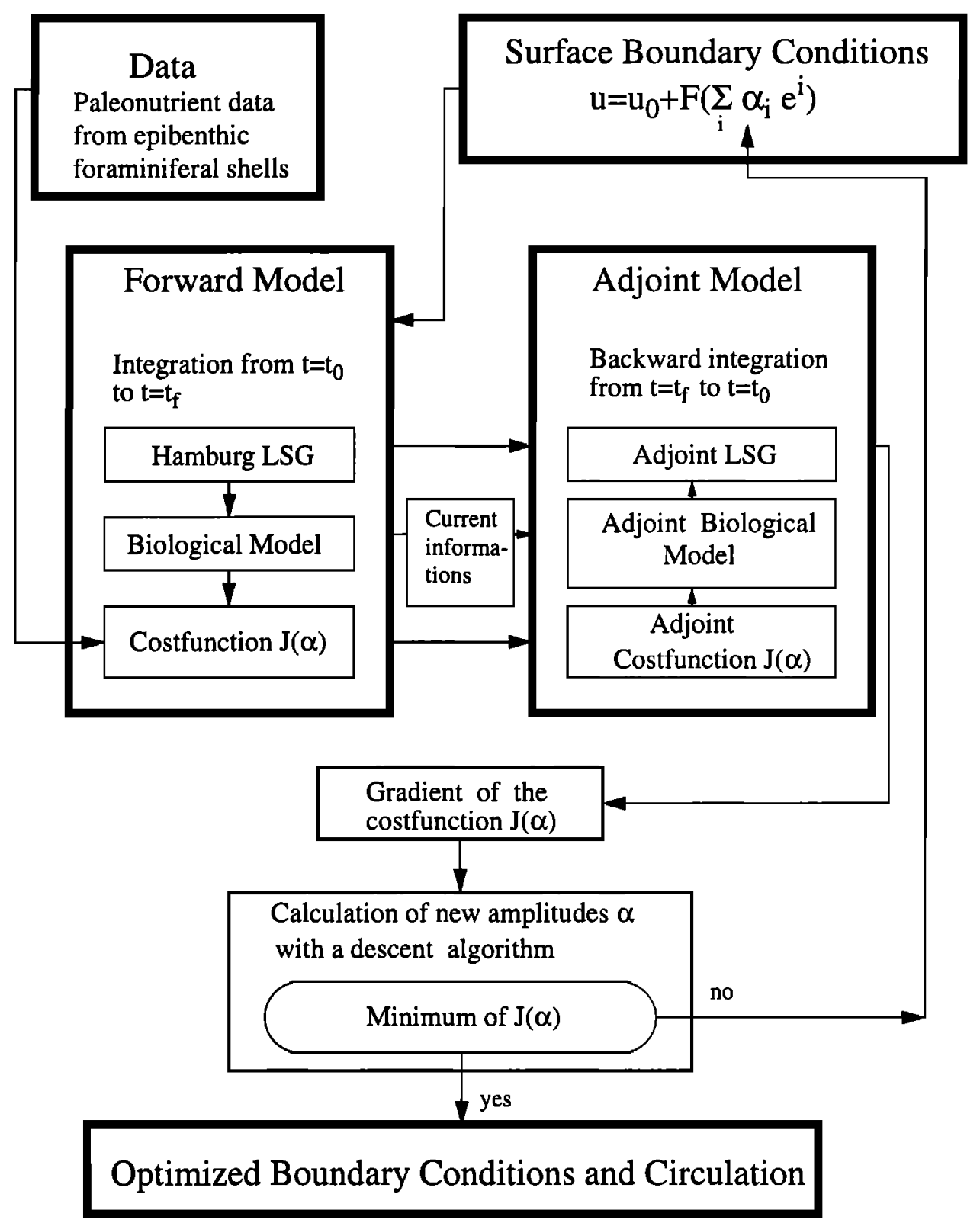

Figure 1. Configuration of the inverse model.

LSG compiled by Giering [1996] due to further development of the forward model (e.g. different treatment of the calculation of the baroclinic velocities, changes in the ice model, and incorporation of tracers and biogeochemistry) as well as different treatment for implicit loops in the adjoint model code. The correctness of the gradients has been tested by first order perturbations of the model [Long, personal communication, 1993] and with artificial data sets studied by Winguth [1997].

\subsection{Minimization Algorithm}

A descending algorithm, the M1QN3-Module from Gilbert and Lemaréchal [1989] which is a limited-memory quasi-Newton-Method (QN), has been used to calculate the corrected control variables - the new guess. With this guess a new cost function and gradient can be calculated. The descending procedure is successively continued until a minimum is found. The M1QN3- 
Module computes a local approximative Hessian matrix from the gradients of the cost function. Thus, a much higher convergence rate in finding a minimum can be reached in comparison with the conventional conjugate gradient method.

One of the major problems in applying the optimization technique to an OGCM is the successful search for a global minimum of the cost function. Thus, the first guess should be close to the global minimum to avoid a convergence in local minima. There are systematic methods to avoid convergence in local minima like simulated annealing [Barth and Wunsch, 1990; Krüger, 1993] or the use of different initial conditions to confirm the finding of a global minimum (see e.g. Schiller and Willebrand [1995]). However, these methods are currently too expensive in numerical and computational costs to allow an application for our model.

\section{RESULTS OF THE DATA ANALYSIS}

In the simulations presented here, the adjoint OGCM has been applied to optimize the flow field of the deepsea for the present and for the LGM. Winguth [1997] used identical twin experiments to demonstrate that the adjoint approach works well as a means to reconstruct surface boundary conditions from the distribution of nutrients in the deep-sea. Based on observed radiocarbon differences between the surface and the deep-sea, OGCMs are generally spun up a couple of thousand years to simulate the steady state of the ocean circulation. However, past computational capacities limited the integration of inverse OGCMs to a length in the integration times of less than a few decades [Tziperman et al., 1992; Marotzke and Wunsch, 1993; Schiller and Willebrand, 1995; Giering, 1996; Winguth, 1997]. These studies discussed the quality of the assimilation as a function of integration time of the inverse OGCM and concluded that an increase in the integration interval would considerably improve the reconstruction of nonlinear processes such as convective mixing, sea ice formation, and biogeochemistry and hence would improve the quality of the deep-sea circulation and tracer distribution. Results from identical twin experiments [Winguth, 1997] suggest that even if perfect data are used the decline of the cost function is strongly dependent on the length of the integration time for the inverse model.

Here, we integrated the model 300 years in time which allows us to interpret the circulation of the deep Atlantic. We have split the model trajectory, which contains current informations at time $t$ of the forward model needed for the adjoint model (Figure 1), into
$\mathrm{N}=60$ trajectories with length of $\Delta t=5$ yrs each to reduce the amount of storage limited by our computational resources. At first, a forward integration of the model from the initial conditions at time $t_{0}$ to the final conditions at $t_{f}$ generates restart files which are stored (checkpointed) every five years. These restart files at time $t_{r}=t_{0}+\mathrm{n} \Delta t$ (with $0 \leq \mathrm{n} \leq \mathrm{N}-1$ ) are used as initial conditions for the model trajectory from $t_{r}$ to $t_{r}+\Delta t$ with a length of five years, which delivers the current information for the adjoint model at time $t=t_{r}+t_{l}$ (with $t_{l}=0 \leq 1 \leq \Delta t$ ). Applying the checkpointing technique reduces the storage required for this time frame to $\sim 1 / 60$, but increases the cost of additional computations.

\subsection{Estimated Circulation in the Present Atlantic}

In order to create a reference and a model error estimate for the glacial circulation, an assimilation experiment with modern surface boundary conditions has been carried out. This experiment is referred to as the Interglacial Second Guess (ISG). Here, we have taken the flow field IFG experiment of Winguth et al. [1999] as a first guess for the modern reference state (Figure 2a). This experiment restores the surface layer to monthly mean COADS air temperatures [Woodruff et al., 1987], annual mean surface salinities [Levitus, 1982] ((Figure 3a) and wind stress of the atmospheric model ECHAM3/T42 [Lorenz et al., 1996] and the ocean circulation is comparable with that from ATOS1 run produced by Maier-Reimer et al. [1993]. The optimization procedure has been applied 8 times until changes in the different contributions of the cost function were smaller than $1 \%$ (Table 1).

The optimized modern circulation state differs little from the first guess salinity (with a $\pm 0.2 \%$ anomaly, Figure $3 \mathrm{~b}$ ) and circulation. A weak positive salinity anomaly in the North Atlantic causes an increase in convective overturning, an increase in the North Atlantic deep circulation (Figure 2c), a weakening of the inflow of Antarctic Bottom Water, and a lowering in the deep phosphate concentration. Consequently, "Nutrient trapping" [Najjar et al., 1992] (a simulated high nutrient concentration in the equatorial subsurface generated by an overestimated export production) is significantly reduced by the data assimilation.

\subsection{Estimated Circulation in the Atlantic During the Last Glacial Maximum}

Initial conditions for the glacial assimilation experiment (GSG) were taken from experiment GFG of Winguth et al. [1999] based on the following LGM sur- 
a) First guess, modern

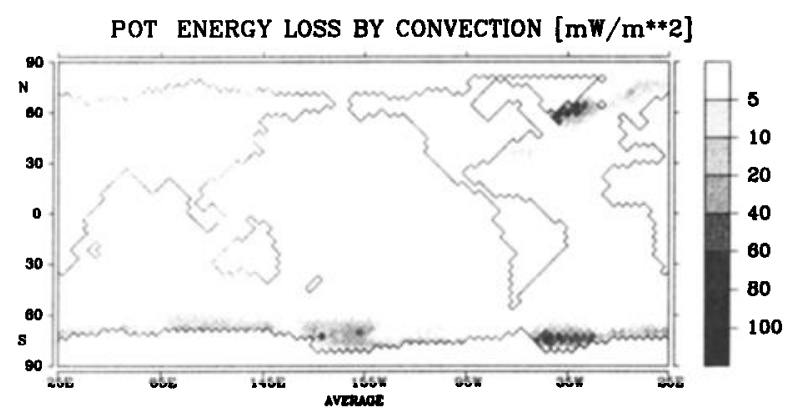

b) First guess, LGM

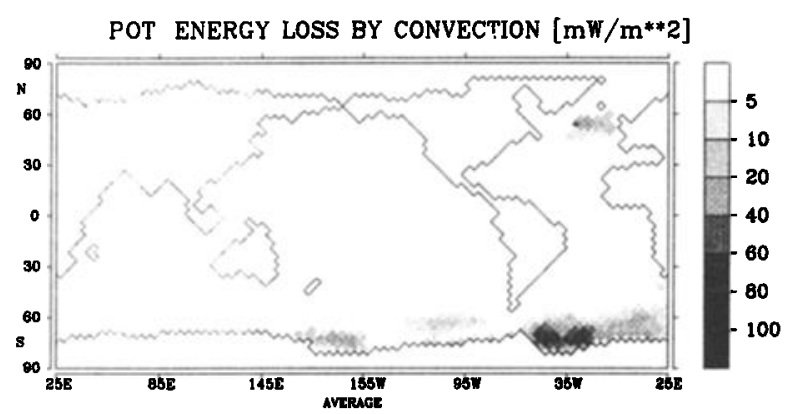

c) Optimized state, modern

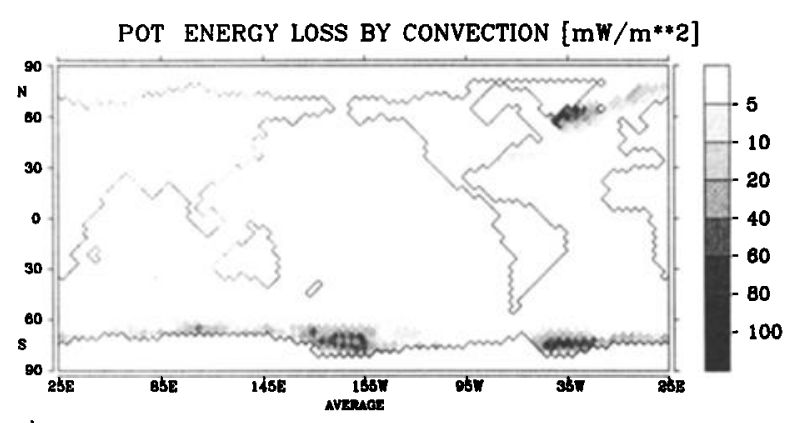

d) Optimized state, LGM

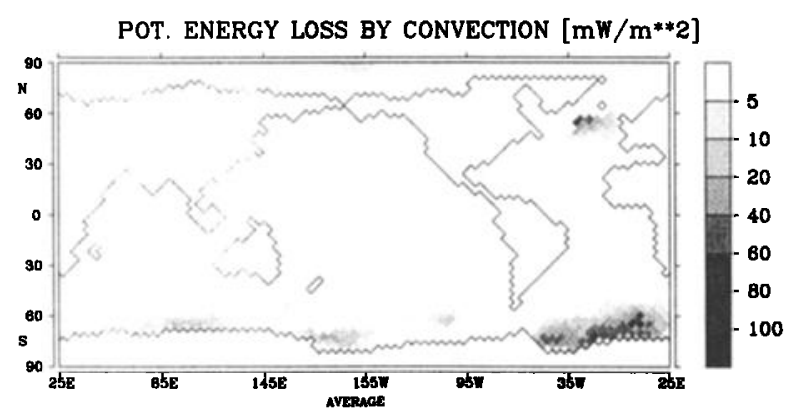

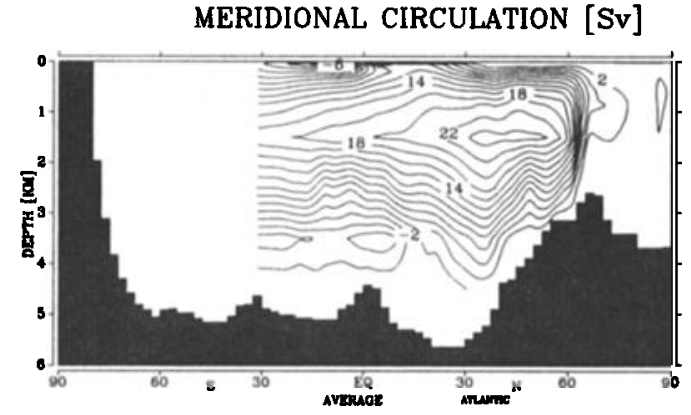
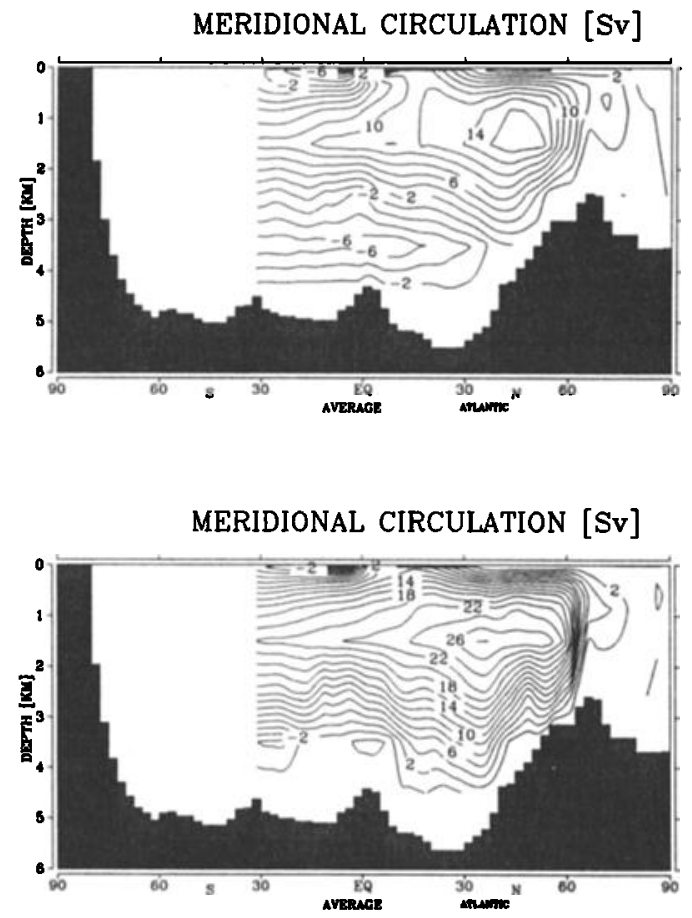

MERIDIONAL CIRCULATION [SV]

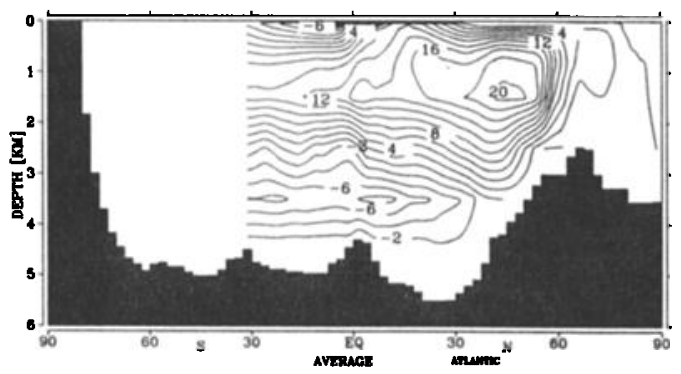

Figure 2. OGCM response to modern and LGM boundary conditions (first guess experiments IFG (a) and GFG (b), and assimilation experiments ISG (c) and GSG (d)). Left: Potential energy loss due to convection. Right: Zonally averaged Atlantic meridional circulation (contour interval: $\left.2 \mathrm{~Sv}=2 \times 10^{6} \mathrm{~m}^{3} \mathrm{~s}^{-1}\right)$. 
a)

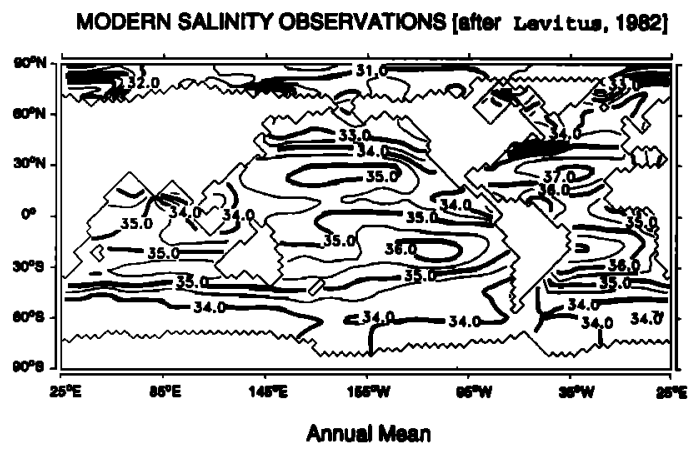

c)
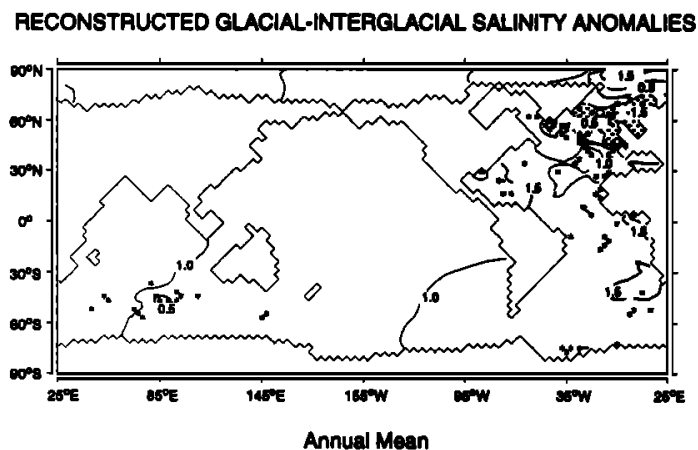

b)

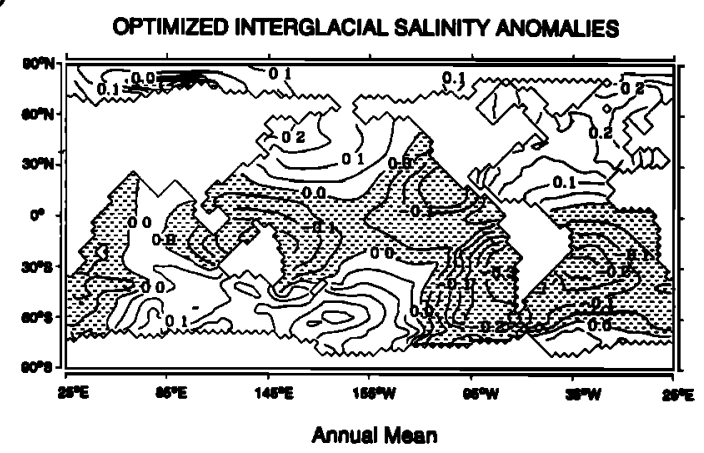

d)
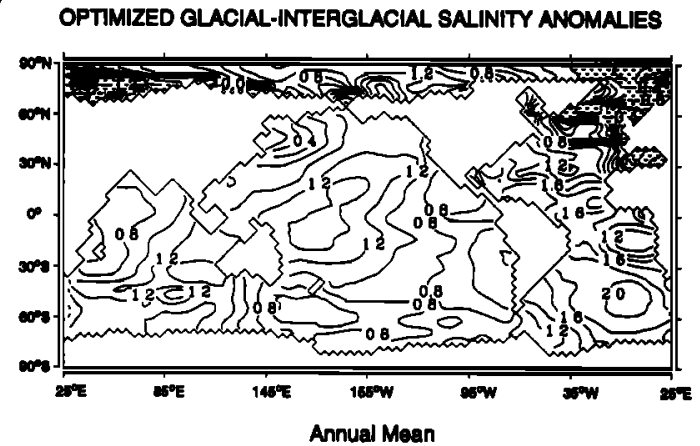

Figure 3. Salinity at the sea surface. (a) Modern observations [Levitus, 1982](contour interval: 0.5 psu), (b) optimized anomalies for modern times gained by assimilation of $\delta^{13} \mathrm{C}$ and $\mathrm{Cd} / \mathrm{Ca}$ data at the available sediment core sites into an OGCM (experiment ISG minus IFG, contour interval: $0.05 \mathrm{psu}$ ), (c) reconstructed glacial-interglacial anomalies from Duplessy et al. [1991; 1996], interpolated to the model grid (contour interval: $0.5 \mathrm{psu}$ ), and (d) optimized glacial-interglacial anomalies gained by assimilation of $\delta^{13} \mathrm{C}$ and $\mathrm{Cd} / \mathrm{Ca}$ data into an OGCM (experiment GSG minus ISG, contour interval: $0.2 \mathrm{psu}$ ). Stars denote geographical positions of data.

face boundary conditions: Wind stress and $2 \mathrm{~m}$ air temperature were taken from the PMIP study with the ECHAM3/T42 atmospheric GCM [Lorenz et al., 1996]. We used prescribed LGM surface salinities instead of fresh water fluxes from PMIP ice-age simulations because Lautenschlager et al. [1992] showed that uncertainties of these fluxes can cause large disagreements in $\delta^{13} \mathrm{C}$ between the data and the model counterparts. Surface salinities were derived from stable oxygen isotope measurements in foraminifera shells [Duplessy et al., 1991; Duplessy et al., 1996] including a correction within the observational uncertainty as described in Winguth et al. [1999] (Figure 3c). The optimization procedure was applied 7 times until the successive reduction of the data cost function was less than $1 \%$. The total decrease of the data cost function at the final state was $\sim 25 \%$ (Table 1 and Figure 4).

Since the use of adjoint method provides by definition a solution consistent with the dynamics of the model [LeDimet and Talagrand, 1986], the remaining

Table 1. Normalized Cost Function

\begin{tabular}{ccccccc}
\hline Experiment & $J_{\text {TOT }}$ (First Guess) & $J_{\text {TOT }}$ (Opt.) & $J_{\mathrm{D}}$ (First Guess) & $J_{\mathrm{D}}$ (Opt.) & $J_{\mathrm{C} 13}$ (Opt.) & $J_{\mathrm{w}}$ (Opt.) \\
\hline \multirow{2}{*}{ ISG } & 1.00 & 0.95 & 1.00 & 0.90 & 0.04 & 0.01 \\
GSG & 1.00 & 0.97 & 1.00 & 0.74 & 0.17 & 0.07 \\
\hline
\end{tabular}

Normalized total cost function $J_{\text {TOT }}$ and contributions of data cost function $J_{D}$ and penalty terms $\left(J_{\mathrm{C} 13}\right.$ and $J_{\mathrm{w}}$ ) which measure the difference to the first guess $\delta^{13} \mathrm{C}$ and vertical velocities. 
a)

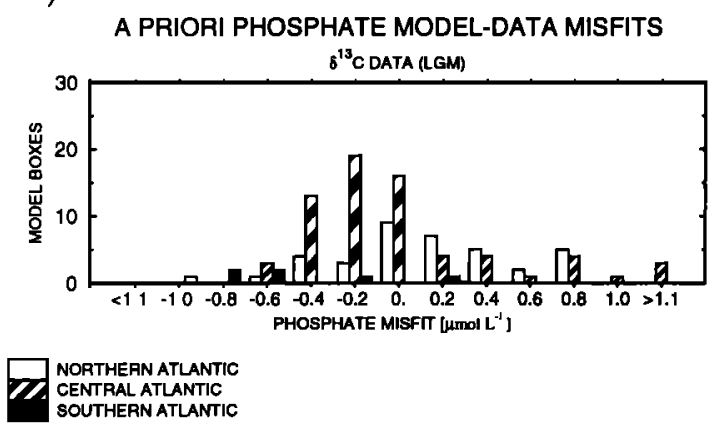

c)

A POSTERIORI PHOSPHATE MODEL-DATA MISFITS

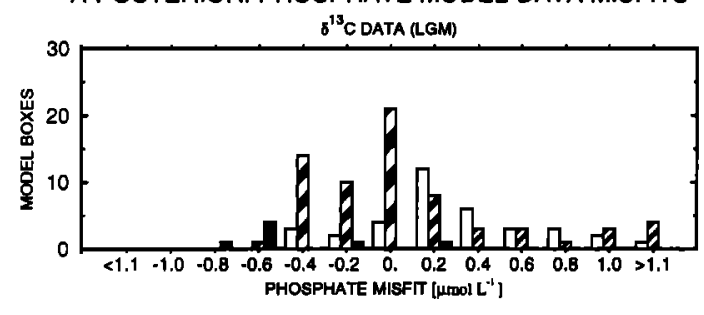

NORTHERN ATLANTIC CENTRAL ATLANTIC
SOUTHERN ATLANTIC b)

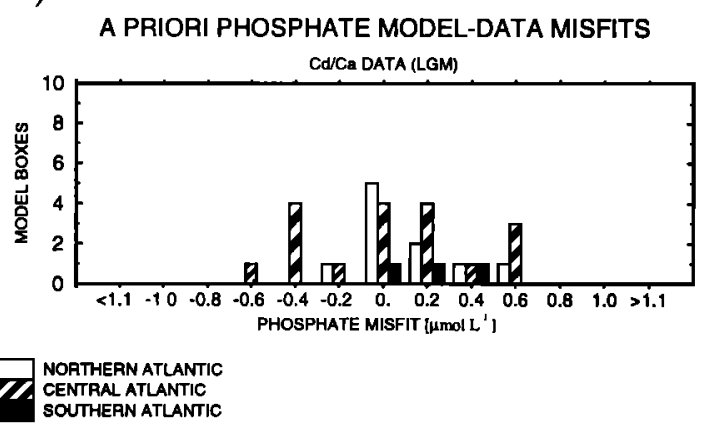

d)
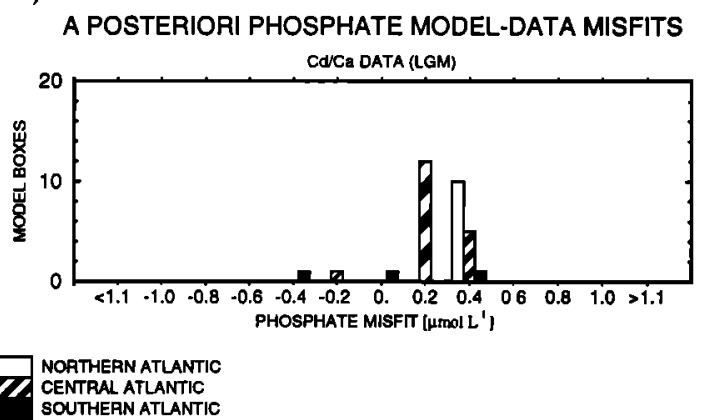

Figure 4. Histogram of paleonutrient misfits between measurements in benthic foraminifera shells and model values in the Atlantic Ocean for the LGM. a) a priori misfit to $\delta^{13} \mathrm{C}$ data, b) a priori misfit to $\mathrm{Cd} / \mathrm{Ca}$ data, c) a posteriori misfit to $\delta^{13} \mathrm{C}$ data, and d) a posteriori misfit to $\mathrm{Cd} / \mathrm{Ca}$ data $\left(\delta^{13} \mathrm{C}\right.$ after Sarnthein et al. [1994]; Michel et al. [1995]; Cd/Ca ratios after Boyle [1992]; see also text).

residual might be related to an underestimation of the observational errors, the approximations for non-linear processes due to a limited integration time, a too high confidence of the OGCM used in this study, a local minimum, the weight of the penalty terms and/or the choice of the first guess. Further, Winguth et al. [1999] showed that the relation between the strength of the deep western boundary currents and changes in the Eastern Atlantic $\delta^{13} \mathrm{C}$ are only loosely correlated with the strength of the western boundary currents. Also, the gaussian assumption for the model and data uncertainties might not be adequate. However, it is generally not very easy or impossible to check the correctness of these assumptions [Bennet, 1992]. Although the deviations of the model-data differences are still higher than the data uncertainties the results are significantly closer to the observed data base than the first guess from Winguth et al. [1999].

Optimized surface salinities (Figure 3d) are closer to the reconstructions of Duplessy et al. $[1991 ; 1996]$ than the first guess salinities. They cause an increase of up- per deep-water formation in the North Atlantic (Figure 2d), also referred to as the glacial North Atlantic Intermediate Water, consistent with interpretations of Duplessy et al. [1988] suggesting high $\delta^{13} \mathrm{C}$ and low nutrient water. These results are supported by recent coupled ocean-atmospheric model simulations [Ganopolski et al., 1998]. The outflow of NCW into the Southern Ocean is 2 Sv higher than in the GFG, but $50 \%$ lower than in the optimized modern circulation in ISG. Strong convective activity in the southern ocean accompanied with nutrient rich water dominates lower deep water in the North Atlantic.

A relatively high salinity anomaly in the western tropical Atlantic is supported by measurements in planktonic $\delta^{18} \mathrm{O}$ [Broecker, 1989]. The features of low salinities in the tropical upwelling region and high salinities in the area of the North Equatorial current also generally agree with the fresh water flux pattern obtained by the ice-age simulation with the ECHAM3/T42 atmospheric GCM by Lorenz et al. [1996]. However, we emphasize that the optimized pattern is mainly linked 


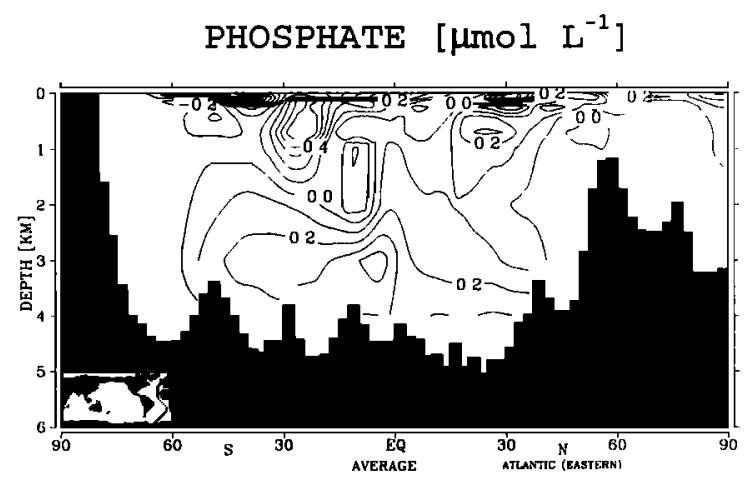

Figure 5. Vertical section of the phosphate concentration in the Eastern Atlantic. Glacial-interglacial differences gained by assimilation of paleonutrient data into an OGCM (experiment GSG minus ISG; contour interval 0.1 $\left.\mu \mathrm{mol} \mathrm{L}{ }^{-1}\right)$.

to salinity changes in regions of deep water formation which influence the strength of the deep-sea circulation significantly.

Our model results confirm previous sensitivity experiments with a coupled ocean and carbon cycle model of Winguth et al. [1999] which showed that the glacialinterglacial changes in the Southern Ocean phosphate cannot explain the large shifts in the stable carbon isotopes (Figure 5). In the South Atlantic (south of $30^{\circ} \mathrm{S}$ ), model-data differences for $\delta^{13} \mathrm{C}$ are about 2-3 times higher than for $\mathrm{Cd} / \mathrm{Ca}$. However, differences to the first guess are significantly influenced by the paleonutrients of the deep eastern Atlantic, where most of the data are available (Figure 4).

\section{CONCLUSION AND SUMMARY}

Our assimilation experiments with an OGCM suggest:

Optimized glacial-interglacial surface salinities require a strong positive fresh water anomaly in the North Atlantic, consistent with observations from $\delta^{18} \mathrm{O}$ in planktonic foraminifera [Duplessy et al., 1991]. A 25\% reduction of the data-model misfit in this study is a significant improvement of previous attempts of Winguth et al. [1999] to simulate the glacial ocean circulation. We simulate for the LGM a southward flow of North Atlantic Deep Water into the Southern Ocean which was shallower and 30-50\% slower than the modern reference, accompanied with a strong source of glacial North Atlantic Intermediate Water, which is in qualitative agreement with interpretations of Duplessy et al. [1988].

Our model results appear to differ with the assertion of LeGrand and Wunsch [1995], that the paleonutri- ent distribution itself is inadequate to distinguish between the present-day circulation and a $50 \%$ reduction of North Atlantic Deep Water (NADW) formation. Differences to their findings might be attributed to the uncertainties in the quantification of northern and southern water mass end members in their regional model and due to a more complex treatment of the physical equations and the consideration of geochemical processes in our OGCM.

However, since differences between the OGCM and the data remain, significant residuals might be related to the following uncertainties: For example,

1. Model equations are assumed to be perfect and an explicit model error is not considered in the inverse formulation. The results strongly depend on the way the model is parametrized (e.g., internal friction, choice of numerical scheme, model resolution, formulation of the boundary conditions [Mikolajewicz and Maier-Reimer, 1994; Rahmstorf and England, 1997], topography [McDermott, 1996], or formulation of biogeochemical processes [Heinze et al.,1999; Archer et al., 1999], etc.).

2. Reevaluation of CLIMAP [1981] sea surface temperatures in high latitudes [Weinelt et al., 1996; A. de Vernal, personal communication, 1997] affects buoyancy and momentum fluxes, which can lead to considerably different solutions in the coupled atmosphere-ocean system.

3. Uncertainties within the paleonutrient tracer observations, the sparse spatial distribution, and the assumption of the observational distribution function and variance influence adversely the quality of the assimilation approach.

4. Residuals might also be related to the approximations for non-linear processes due to a limited integration time, a local minimum, the weight of the penalty terms and/or the choice of the first guess.

Our simulated glacial to interglacial changes in phosphate in the Southern Ocean agree generally with the $\mathrm{Cd} / \mathrm{Ca}$ distribution. The model simulation cannot explain the large $\delta^{13} \mathrm{C}$ shifts (in terms of normalized phosphate units) in the benthic foraminifera. The large $\delta^{13} \mathrm{C}$ shifts from glacial to interglacial observed in some benthic foraminifera were directly under high productivity zones [Rosenthal et al., 1997] and might be influenced by sediment pore water [Mackensen et al., 1993]. Possible changes in the postdepositional dissolution, inventories and a change in the $\mathrm{pH}$ value might play an important role in this region. Also, the model cannot resolve eddies and we do not consider any shift in the Redfield Ratio (e.g., a decoupling of the linear relationship between the $\mathrm{P}: \mathrm{N}$ ratio related to iron fertilization) 
as discussed in Broecker and Henderson [1998]. Most of the paleonutrient data are available in the northern and eastern Atlantic and optimized anomalies are influenced mainly by these data. Thus we conclude, there is a need for a much larger data base along the deep western boundary currents and in the Southern Ocean to constrain future model simulations with higher spatial resolution and improved biogeochemistry. We also suggest that additional paleoceanographic tracers should be used simultaneously in future efforts (such as e.g. $\mathrm{Pa} / \mathrm{Th}$ [Heinze et al., 1999; Henderson et al., 1999]) to interpret the past ocean circulation.

\section{NOTATION}

\begin{tabular}{|c|c|}
\hline $\begin{array}{l}\alpha \\
\delta^{13} \mathrm{C}_{\text {tot }}\end{array}$ & $\begin{array}{l}\text { amplitudes of orthogonal functions e } \\
\text { total } \delta^{13} \mathrm{C} \text { distribution }\end{array}$ \\
\hline$\delta^{13} \mathrm{C}_{\text {bio }}$ & biological effect of $\delta^{13} \mathrm{C}$ distibution \\
\hline$\delta^{13} \mathrm{C}_{\mathrm{as}}$ & $\begin{array}{l}{ }^{13} \mathrm{C} /{ }^{12} \mathrm{C} \text { air-sea gas exchange } \\
\text { effect on the surface }\end{array}$ \\
\hline $\mathbf{e}$ & orthogonal functions of model grid \\
\hline$J_{\text {TOT }}$ & total cost function \\
\hline$J_{\mathrm{D}}$ & data cost function \\
\hline$J_{\mathrm{P}}$ & penalty cost function for phosphate \\
\hline$J_{\mathrm{w}}$ & $\begin{array}{l}\text { penalty cost function for } \\
\text { vertical velocities }\end{array}$ \\
\hline $\mathbf{P}_{\mathrm{P}}$ & $\begin{array}{l}\text { covariance matrix for phosphate } \\
\text { state vector }\end{array}$ \\
\hline $\mathbf{P}_{\mathbf{w}}$ & $\begin{array}{l}\text { covariance matrix for vertical } \\
\text { velocity state vector }\end{array}$ \\
\hline $\mathbf{R}$ & observation covariance matrix \\
\hline$\sigma_{\mathrm{D}}$ & $\begin{array}{l}\text { standard deviation for paleonutrient } \\
\text { observations }\end{array}$ \\
\hline$\sigma_{\mathrm{P}}$ & standard deviation for phosphate \\
\hline$\sigma_{\mathrm{w}}$ & standard deviation for vertical velocities \\
\hline$t$ & time \\
\hline & salinity boundary conditions \\
\hline$V_{\text {TOT }}$ & total volume of all ocean boxes \\
\hline$V_{\mathrm{D}}$ & $\begin{array}{l}\text { sum of all box volumes used in the } \\
\text { nearest vicinity of observations }\end{array}$ \\
\hline$W_{\mathbf{w}}$ & $\begin{array}{l}\text { weight for penalty cost function } \\
\text { for vertical velocities }\end{array}$ \\
\hline$W_{\mathrm{n}}$ & weight for locations of observations \\
\hline $\mathbf{x}_{\mathrm{P}}$ & phosphate state vector \\
\hline $\mathbf{x}_{\mathbf{w}}$ & vertical velocity state vector \\
\hline $\mathbf{y}^{0}$ & observations \\
\hline $\mathbf{z}$ & depth \\
\hline
\end{tabular}

Acknowledgments. We thank Doug MacAyeal and Cornelia Winguth for reading this manuscript and Ralf Giering for fruitful discussion. Also thanks to Scott Doney for constructive remarks and to Jean-Michel Campin, JeanClaude Duplessy, Elisabeth Michel, and Stefan Lorenz for having provided the data used in this study. This work was partly done at the Max-Planck-Institut (supported by the Deutsche Forschungsgemeinschaft Grant No. DFG Ma 1070/2-1) and partly at the University of Chicago (supported by the Packard Foundation).

\section{REFERENCES}

Archer, D., A. Winguth, D. Lea, and N. Mahowald, What causes the glacial/interglacial $\mathrm{pCO}_{2}$ cycles?, Reviews of Geophysics, submitted, 1999.

Arakawa, A., and V.R. Lamb, Computational design of the basic dynamical processes of the UCLA general circulation model, Methods Comput. Phys., 16, 173-283, 1977.

Barth, N., and C. Wunsch, Oceanographic experiment design by simulated annealing, J. Phys. Oceanogr., 20, 1249$1263,1990$.

Bennet, A.F., Inverse methods in physical oceanography, Cambridge Monographs on mechanics and applied mathematics, edited by G.K. Batchelor and L.B. Freud, 346 pp., Cambridge University Press, Cambridge, U.K., 1992.

Boyle, E.A., Cadmium: Chemical tracer of deepwater paleoceanography, Paleoceanography, 3, 471-489, 1988.

Boyle, E.A., Cadmium and $\delta^{13} \mathrm{C}$ paleochemical ocean distributions during stage 2 glacial maximum, Annu. Rev. Earth Planet. Sci., 20, 245-287, 1992.

Broecker, W.S., The salinity contrast between the Atlantic and Pacific oceans during the last glacial time, Paleoceanography, 4, 207-212, 1989.

Broecker, W.S., An oceanographic explanation for the apparent carbon isotope-cadmium discordancy in the glacial Antarctic, Paleoceanography, 8, 137-139, 1993.

Broecker, W.S., and E. Maier-Reimer, The influence of air and sea exchange on the carbon isotope distribution in the sea, Global Biogeochem. Cycles, 6, 315-320, 1992.

Broecker, W.S., and G.M. Henderson, The sequence of events surrounding Termination II and their implications for the cause of glacial-interglacial $\mathrm{CO}_{2}$ changes, Paleoceanography, 13, 352-364, 1998.

Bush, A.B., and S.G.H. Philander, The role of ocean-atmosphere interactions in tropical cooling during the Last Glacial Maximum, Science, 297, 1341-1344, 1998.

Climate: Long-Range Investigation, Mapping, and Prediction (CLIMAP) Project Members, Seasonal reconstruction of the the Earth's surface at the Last Glacial Maximum, Geol. Soc. Am. Map Chart Ser., MC-36, 1981.

Crowley, T.J., Ice age terrestrial carbon changes revisted, Global Biogeochem. Cycles, 9, 377-389, 1995.

Duplessy, J.-C., N.J. Shackleton, R.G. Fairbanks, L.D. Labeyrie, D. Oppo, and N. Kallel, Deep water source variations during the last climatic cycle and their impact on the global deepwater circulation, Paleoceanography, 3, 343360, 1988.

Duplessy, J.-C., L.D. Labeyrie, A. Juillet-Leclerc, F. Maitre, J. Dupart, and M. Sarnthein, Surface salinity reconstruction of the North Atlantic Ocean during the Last Glacial Maximum, Oceanolog. Acta, 14, 311-324, 1991.

Duplessy, J.-C., L.D. Labeyrie, M. Paterne, S. Hovine, T. Fichefet, J. Duprat, and M. Labracherie, High latitude deep water sources during the Last Glacial Maximum and the intensity of the global oceanic circulation, in 
The South Atlantic, edited by G. Wefer, W.H. Berger, G. Siedler and E. Webb, pp. 445-460, Springer-Verlag, New York, 1996.

Farrera, I., et al., Tropical climate at the last glacial maximum: a new synthesis of terrestrial paleoclimate data. I. Vegetation, lake-levels and geochemistry, Climate Dyn., in press, 1999.

Fichefet, T., S. Hovine, and J.-C. Duplessy, A model study of the Atlantic thermohaline circulation during the last glacial maximum, Nature, 372, 252-255, 1994.

Fieg, K., Der Ozean als Teil des gekoppelten Klimasystems: Versuch der Rekonstruktion der glazialen Zirkulation mit verschieden komplexen Atmosphärenkomponenten, $B e$ richte zur Polarforschung, 206, Alfred-Wegener-Institut für Polar- und Meeresforschung, Bremerhaven, 1996.

Francois, R., M.A. Altabet, E.-F. Yu, D.M. Sigman, M.P. Bacon, M. Frank, G. Bohrmann, G. Bareille and L.D. Labeyrie, contribution of Southern Ocean surface-water stratification to low atmospheric $\mathrm{CO}_{2}$ concentration during the last glacial period, Nature, 389, 929-936, 1997.

Ganopolski, A., S. Rahmstorf, V. Petoukhov, and M. Clausen, Simulation of modern and glacial climates with a coupled global model of intermediate complexity, Nature, 391, 351-356, 1998.

Giering, R., Tangent linear and adjoint biogeochemical models, this volume, 1999, American Geophysical Union.

Giering, R., Erstellung eines adjungierten Modells zur Assimilierung von Daten in ein Modell der globalen ozeanischen Zirkulation, Examensarbeit Nr. 44, Max-PlanckInst. für Meteorol., Hamburg, Germany, 1996.

Giering, R., and T. Kaminsky, Recipes for Adjoint Code Construction, Rep. 212, Max-Planck-Inst. für Meteorol., Hamburg, Germany, 1996.

Gilbert, J.C., and C. Lemaréchal, Some numerical experiments with variable storage quasi-Newton algorithms, Mathematical Programming, 45, 407-435, 1989.

Guilderson, T.P., R.G. Fairbanks, and J.L. Rubenstone, Tropical temperature variations since 20,000 years ago: Modulating interhemispheric climate change, Science, 263 , 663-665, 1994.

Joussaume, S., and K.E. Taylor, Status of the Paleoclimate Modeling Intercomparison Project (PMIP), in: Proceedings of the First International AMIP scientific Conference (Monterey, California, USA, 15.19 May 1995), WCRP Report, 92, 425-430, 1995.

Heinze, C., E. Maier-Reimer, A. Winguth, and D. Archer, A global oceanic sediment model for longterm climate studies, Global Biogeochem. Cycles, 13, 221-250, 1999.

Henderson, G.M., C. Heinze, R. Anderson, and A. Winguth, Global distribution of the ${ }^{230} \mathrm{Th}$ flux to ocean sediments constrained by GCM modelling, Deep-Sea Res., in press, 1999.

Herterich K., S. Determann, B. Grieger, I. Hansen, P. Helbig, S. Lorenz, A. Manschke, M. Matthies, A. Paul, R. Schlotte, and U. Wyputta, Reconstructing and modelling the Last Glacial Maximum: Beyond CLIMAP, in Proxies in Paleoceanography, edited by G. Wefer and G.F. Fischer, in press, 1999.

Krüger, J., Simulated annealing: A tool for data assimilation into an almost steady model state, J. Phys. Oceanogr., 23, 679-688, 1993.

Labeyrie, L.D., J.-C. Duplessy, J. Dupart, A. Juillet-Leclerc,
J. Moyes, E. Michel, N. Kallel, and N.J. Shackleton, Changes in the vertical structure of the North Atlantic Ocean between glacial and modern times, Quat. Sci. Rev., 11, 401-413, 1992.

Lautenschlager, M., U. Mikolajewicz, E. Maier-Reimer, and C. Heinze, Application of ocean models for the interpretation of atmospheric general circulation model experiments on the climate of the Last Glacial Maximum, Paleoceanography, 7, 769-782, 1992.

LeDimet, F., and O. Talagrand, Variational algorithms for analysis and assimilation of meteorological observations: theoretical aspects, Tellus, 38 A, 97-110, 1986.

LeGrand, P., and C. Wunsch, Constraints from paleotracer data on the North Atlantic circulation during the Last Glacial Maximum, Paleoceanography, 10, 1011-1045, 1995.

Levitus, S., Climatological Atlas of the World Ocean, Prof. Pap., 13, Nat. Oceanic and Atmos. Admin., Rockville, Md., 1982.

Lorenz, S., B. Grieger, P. Helbig, and K. Herterich, Investigating the sensitivity of the Atmospheric General Circulation Model ECHAM 3 to paleoclimatic boundary conditions, Geol. Rundsch., 85, 513-524, 1996.

Mackensen, A., Foraminiferen und Paläoozeanographie hoher Breiten, Ber. Polarforsch., 243, Alfred-Wegener-Inst. für Polar- und Meeresforsch., Bremerhaven, Germany, 1997.

Mackensen, A., H.-W. Hubberten, T. Bickert, G. Fischer, and D.K. Fütterer, The $\delta^{13} \mathrm{C}$ in benthic foraminiferal tests of Fontbotia wuellerstorfi (Schwager) relative to the $\delta^{13} \mathrm{C}$ of dissolved inorganic carbon in Southern Ocean Deep Water: Implications for glacial ocean circulation models, Paleoceanography, 8, 587-610, 1993.

Mackensen, A., H.-W. Hubberten, N. Scheele and R. Schlitzer, Decoupling of $\delta^{13} \mathrm{C}_{\Sigma \mathrm{CO} 2}$ and phosphate in recent Weddel Sea deep and bottom water: Implications for glacial Southern Ocean paleoceanography, Paleoceanography, 11, 203-215, 1996.

Maier-Reimer, E., Geochemical cycles in an ocean general circulation model. Preindustrial tracer distributions, Global Biogeochem. Cycles, 7, 645-677, 1993.

Maier-Reimer, E., U. Mikolajewicz, and K. Hasselmann, Mean circulation of the Hamburg LSG OGCM and its sensitivity to the thermohaline surface forcing, $J$. Phys. Oceanogr., 23, 731-757, 1993.

Marotzke, J., and C. Wunsch, Finding the steady state of a general circulation model through data assimilation: Application to the North Atlantic Ocean, J. Geophys. Res., 98 (C11) 20,149-20,167, 1993.

McCorkle, D.C., and L.D. Keigwin, Depth profile of $\delta^{13} \mathrm{C}$ in bottom water and core top C. wuellerstorfi on the Ontong Java Plateau and Emperor Seamounts, Paleoceanography, 9, 197-208, 1994.

McDermott, D.A., The regulation of northern overturning by Southern Hemisphere winds, J. Phys. Oceanogr., 26, 1234-1255, 1996.

Michel, E., L.D. Labeyrie, J.-C. Duplessy, and N. Gorfi, Could deep Subantarctic convection feed the world deep basins during the last glacial maximum?, Paleoceanography, 10, 927-942, 1995.

Mikolajewicz, U., A meltwater induced collapse of the "conveyor belt" thermohaline circulation and its influence on the distribution of $\Delta^{14} \mathrm{C}$ and $\delta^{18} \mathrm{O}$ in the oceans, Rep. 
189, Max-Planck-Inst. für Meteorol., Hamburg, Germany, 1996.

Mikolajewicz, U., and E. Maier-Reimer, Mixed boundary conditions in ocea $\mathrm{n}$ general circulation models and their influence on the stability of the model's conveyor belt, $J$. Geophys. Res., 98 (C11), 22,633-22,644, 1994.

Najjar, R.G., J.L. Sarmiento, and J.R. Toggweiler, Downward transport and fate of organic matter in the ocean: Simulations with a general circulation model, Global Biogeochem. Cycles, 6, 45-76, 1992.

Rahmstorf, S., and M. England, Influence of Southern Hemisphere winds on North Atlantic Deep Water flow, J. Phys. Oceanogr., 27, 2040-2054, 1997.

Rau, G.H., T. Takahashi, D.J. Des Marais, and C.W. Sullivan, Particulate organic matter $\delta^{13} \mathrm{C}$ variations across the Drake Passage, J. Geophys. Res., 96 (C8), 15131-15136, 1991.

Rind, D., and D. Peteet, Terrestrial conditions at the Last Glacial Maximum and CLIMAP sea-surface temperature estimates: Are they consistent?, Quat. Res., 24, 1-22, 1985.

Rosell-Melé, A., and N. Koc, Paleoclimatic significance of the stratigraphic occurence of photosynthetic biomarker pigments in the Nordic Seas, Geology, 25, 49-52, 1997.

Rosenthal, Y., E.A. Boyle, and. L. Labeyrie, Last glacial maximum paleochemistry and deepwater circulation in the Southern Ocean: Evidence from foraminiferal cadmimum, Paleoceanography, 12, 787-796, 1997.

Sanyal, A., N.G. Hemming, G.N. Hanson, and W.S. Broecker, Evidence for a higher $\mathrm{pH}$ in the glacial ocean from boron isotopes in foraminifera, Nature, 373, 234-236, 1995.

Sarnthein, M., K. Winn, S.J.A. Jung, J.-C. Duplessy, L. Labeyrie, H. Erlenkeuser, and G. Ganssen, Changes in east Atlantic deepwater circulation over the last 30,000 years: Eight time slice reconstructions, Paleoceanography, 9, 209-267, 1994.

Schiller, A., and J. Willebrand, A technique for the determination of surface heat and freshwater fluxes from hydrographic observations using an approximate adjoint ocean circulation model, J. Mar. Res., 53, 433-451, 1995.

Seidov, D., and B.J. Haupt, Global ocean thermohaline conveyor at present and in the late Quaternary, Geophys. Res. Lett., 24, 2817-2820, 1997.

Semtner, A.J., Jr. and R.M. Chervin, Ocean general circulation from a global eddy-resolving model, J. Geophys. Res., 97, 5493-5550, 1992.

Shackleton, N.J., Attainment of isotopic equilibrium between ocean water and the benthonic foraminifera genus Uvigerina: Isotopic changes in the ocean during the last glacial, Colloq. Int. Centr. Nat. Rech. Sci., 219, 203-219, 1974.

Sikes, E.L., and L.D. Keigwin, Equatorial Atlantic sea surface temperature for the last $30 \mathrm{kyr}$ : A comparison of $\mathrm{U}_{37}^{k^{\prime}}$, $\delta^{18} \mathrm{O}$ and foraminiferal assemblage temperature estimates, Paleoceanography, 9, 31-45, 1994.

Spero, H.J., J. Bijma, D.W. Lea, and B. Bemis, Effect of seawater carbonate concentrations on foraminiferal carbon and oxygen isotopes, Nature, 390, 497-500, 1997.

Stute, M., M. Forster, H. Frischkorn, A. Serejo, J.F. Clark, P. Schlosser, W. Broecker, and G. Bonani, Cooling of tropical Brazil $\left(5^{\circ}\right)$ during the Last Glacial Maximum, Science, 269, 379-383, 1995.
Talagrand, O., The use of adjoint equations in numerical modeling of the atmospheric circulation, in Automatic Differentiation of Algorithms: Theory, Implementation and Application, edited by A. Griewank and G. Corliess, pp. 169-180, SIAM, Philadelphia, Penn., 1991.

Takahashi, T., W.S. Broecker, and S. Langer, Redfield ratio based on chemical data from isopycnal surfaces, $J$. of Geophys. Res., 90, S. 6907-6924, 1985.

Toggweiler, J.R., and B. Samuels, Is the magnitude of the deep outflow from the Atlantic Ocean actually governed by Southern Hemisphere winds?, in The Global Carbon Cycle, NATO ASI Ser., vol. I15, edited by M. Heimann, pp. 303-331, Springer-Verlag, New York, 1993.

Tziperman, E., W.C. Thacker, and K. Bryan, Computing the steady state oceanic circulation using an optimization approach, Dyn. Atmos. Ocean, 16, 379-403, 1992.

van Oldenborgh, G.J., G. Burgers, S. Venzke, C. Eckert, and R. Giering, Tracking down the ENSO delayed oscillator with an adjoint OGCM, KMNI Report No. 97-23, Koninklijk Nederlands Meteorologisch Institut, De Bilt, 1997.

Weaver, A.J., M. Eby, A.F. Fanning, and E.C. Wiebe, Simulated influence of carbon dioxide, orbital forcing and ice sheets on the climate of the Last Glacial Maximum, $\mathrm{Na}$ ture, 394, 847-853, 1998.

Weinelt, M., M. Sarnthein, U. Pflaumann, H. Schulz, J. Jung, and H. Erlenkeuser, Ice-free Nordic Seas during the last glacial maximum? Potential sites of deepwater formation, Paleoclimates, 1, 283-309, 1996.

Winguth, A.M.E, Assimilation von $\delta^{13}$ C-Daten aus marinen Sedimentbohrkernen in das LSG zur Rekonstruktion der Ozeanzirkulation während des letzten glazialen Maximums, Examensarbeit Nr. 47, Max-Planck-Inst. für Meteorol., Hamburg, Germany, 1997.

Winguth, A.M.E, D. Archer, E. Maier-Reimer, U. Mikolajewicz, and J.-C. Duplessy, Sensitivity of paleonutrient tracer distributions and deep-sea circulation to glacial boundary conditions, Paleoceanography, 14, 304-323, 1999.

Woodruff, S.D., R.J. Slutz, R.L. Jenne, and P.M. Steurer, A comprehensive ocean-atmosphere data set, Bull. Am. Meteorol. Soc., 68, 1239-1250, 1987.

Wunsch, C. (Ed.), The ocean circulation inverse problem, 458 pp., Cambridge Univ. Press, Cambridge, 1997.

Yu, E.-F., R. Francois, and M.P. Bacon, Similar rates of modern and last-glacial ocean thermohaline circulation inferred from radiochemical data, Nature, 379, 689-694, 1996.

Zahn, R., and A.C. Mix, Benthic foraminiferal $\delta^{18} \mathrm{O}$ in the ocean's temperature-salinity-density field: Constraints on ice age thermohaline circulation, Paleoceanography, 6, 120, 1991.

D. Archer and A. M. E. Winguth, Department of Geophysical Sciences, University of Chicago, 5734 S. Ellis Av., Chicago, IL 60637. (email:winguth@starbuck.uchicago.edu, archer@popeye.uchicago.edu)

E. Maier-Reimer and U. Mikolajewicz, Max-PlanckInstitut für Meteorologie, Bundesstr. 55, D-20146 Hamburg, Germany.(email:' maier-reimer@dkrz.de, mikolajewicz@ dkrz.de) 